Interdisciplinary Contexts of Special Pedagogy
No. 25/2019

\title{
The selected premises for the reconfiguration of the disability model. The posthumanist perspective
}

\begin{abstract}
Teresa Żółkowska, Karolina Kaliszewska, The selected premises for the reconfigura-tion of the disability model. The posthu-manist perspective. Interdisciplinary Contexts of Special Pedagogy, no. 25, Poznań 2019. Pp. 55-81. Adam Mickiewicz University Press. ISSN 2300-391X. DOI: https:// doi.org/10.14746/ikps.2019.25.03

In the contemporary special pedagogy, it is clearly seen, that we are dealing with a situation of passing over scholarly programmes that refer, i.a. to the medical and social model of disability. We remain in a inter-paradigmatic transition period, in which new views on disability are appearing. One of the most popular scholarly approaches is the posthumanism, the characteristics of which are, i.a.: the critique of humanism, the departure from anthropocentrism, the appearance of a new materialism, the direction of research towards objects, animals, as well as, the relations of people and non-people. The example of such posthumanist approach, that may constitute the context for the creation of new models of disability, is the Actor-Network theory developed by Bruno Latour and his associates.
\end{abstract}

KEYWORDS: disability, paradigm, posthumanism, the Actor-Network theory

\section{Introduction}

In the contemporary special pedagogy, similar to other disciplines, particularly social, we are increasingly facing changing scholarly approaches, perspectives, or tendencies. Some fade away, 
while others reveal themselves in order to emblazon the changes occurring in the cultural, social and political structures and practices. According to Iwona Chrzanowska "in special pedagogy, similar to pedagogy in general, numerous changes in the approach occurred, according to which basic concepts, and theories were defined. While doing an overview of them, Krause indicates the historical paradigmatic transformations, that became the founding stone of not only definitional and terminological changes in special pedagogy, but also, in consequence, changes in scholarly and interpretation attitudes" 1 .

Within the theoretical plane of special pedagogy, the paradigmatic reconfigurations appear, that determine the spheres of contemporary discourses regarding disabilities, the means of interpreting the phenomenon, and the fields of ground-breaking research². Cultural, social and political changes inspire pedagogues to undertake more and more modern theoretical and practical challenges, including constructing new models of disability.

\section{Model - indication and function}

In my inquiries, I consider model to be a paradigm ${ }^{3}$. According to Ireneusz Bobrowski ${ }^{4}$ it is a set of norms, rules of proceeding, known to every scientist who is dedicated to a given science. Paradigm (from the Greek paradeigma) is a term meaning example, pattern, a schematic model, having a didactic value, allowing for a clear and direct overview of the complex objects of the research ${ }^{5}$.

${ }^{1}$ I. Chrzanowska, Pedagogika specjalna. Od tradycji do wspótczesności. Wydawnictwo Naukowe Impuls, Kraków 2015, p. 397.

2 A. Krause, Wspótczesne paradygmaty pedagogiki specjalnej. Wydawnictwo Impuls, Kraków 2010.

3 T.S. Kuhn, Struktura rewolucji naukowych, (trans.) H. Ostromęcka. Aletheia, Warszawa 2000, p. 248.

${ }^{4}$ I. Bobrowski, Zaproszenie do jezykoznawstwa. Wydawnictwo Instytutu Języka Polskiego PAN, Kraków 1998.

5 S. Rainko, Dwa paradygmaty. Państwowy Instytut Wydawniczy, Warszawa 2011, pp. 95-96. 
According to Kazimierz Jodkowski, paradigm is an ambiguous term, often perceived as an assortment of universally adopted theoretical beliefs (philosophical, natural, or methodological), and the experimental methods. It is a scholarly tradition that shows a group of scientists, how they are supposed to approach phenomena, how to analyse them, what effects should be expected, and what methods must be applied. In other words, it is a way of seeing particular issues, it is a framework for the selection of the scholarly methods, and solution means 6 .

One of the first theoreticians, who defined the concept of paradigm is Georg Ch. Lichtenberg, who considered paradigms to be certain fundamental models of explanation in physical sciences, on which, networks of explanations are being built ${ }^{7}$. The term was also used by Ludwig Wittgenstein ${ }^{8}$ - in his studies regarding the regularities of the development of philosophical thought, and, in a broader context, as a way of understanding the role of models that act as models that shape and direct reflection in, at times, completely different directions ${ }^{9}$. Wittgenstein perceived the paradigm as a model, that serves the purpose of helping to understand the formation of concepts by exposing the examples, typical for a particular concept. According to the author, the catalogues of these examples, changes with time until the moment, when the catalogue becomes so narrow, that it cannot be reduced further, however, due to the acquisition of new knowledge, there is a possibility to expand the list of examples ${ }^{10}$.

${ }^{6}$ K. Jodkowski, Paradygmat. file:/ / C:/Users/user/Desktop/Jodkowski_Para dygmat_1987.pdf, p. 456 and others, Access: 12.04.2019 r.

7 S. Gurtowski, Należeć do wszechświata. Poszukiwania na pograniczu nauki i duchowości, Collectanea Theologica, 1966, 66(4), pp. 207-211.

${ }^{8}$ L. Wittgenstein, Dociekania filozoficzne, (trans.) B. Wolniewicz, Wydawnictwo Naukowe PWN, Warszawa 2004.

${ }^{9}$ A. Motycka, Relatywistyczna wizja nauki. Analiza krytyczna koncepcji T.S. Kuhna i S.E Toulmina. Wydawnictwo PAN, Wrocław 1980, p. 6.

${ }^{10} \mathrm{M}$. Kępa, Metodologiczne ujęcie paradygmatu jako metody badawczej na przykładzie koncepcji Thomasa Kuhna. Wydawca: E-Wydawnictwo. Prawnicza i Ekonomiczna Biblioteka Cyfrowa, Wrocław 2015, p. 362. 
The term paradigm, reached particular popularity at the turn of the 1950s and the 1960s. During this period, a theory of the development of knowledge appeared, presented by Thomas S. Kuhn ${ }^{11}$. Kuhn's approach was used in physical sciences, as well as, in biology, social sciences, history of disciplines such as art, economy, anthropology, psychology, and political sciences. According to the author, during the development of the sciences, one faces brief periods of scientific revolution, as well as, longer periods, when science is developed within the framework of a paradigm ${ }^{12}$. A paradigm, that Kuhn understood as certain accepted models of contemporary scientific practice, referring to laws, theories, applications, and technical equipment, that constitute the model determining a particular, coherent scientific tradition ${ }^{13}$.

In result of long-lasting works on the paradigm, Kuhn proposed its two levels: 1) model -paradigm is a solution to a particular problem, accepted by the scientific community, 2) the matrix of a scientific discipline. Kuhn assumed the elements of the matrix to be; a) symbolical generalisations, i.e. the laws of a theory in a mathematical form, simple to present in a logical, formal form, b) obligations regarding particular models, such as: heuristic models (analogies, comparisons, metaphors), and ontological models - beliefs regarding the ultimate structure, and the mechanism of an examined portion of reality, 3) scientific values, i.e. the rules that direct the scholars during making decisions in scholarly practice, bearing in mind, that the knowledge of these rules is distorted, "silent", 4) models, i.e. solutions to particular problems, acquired by solving exercises and tasks, to which every new problem that found for the first time, is reduced ${ }^{14}$.

11 T.S. Kuhn, Struktura rewolucji naukowych, (trans.) H. Ostromęcka. Aletheia, Warszawa 2001.

12 K. Jodkowski, Paradygmat. file:/ / / C:/Users/user/Desktop/Jodkowski_Para dygmat_1987.pdf, p. 462 and others Access: 12.04.2019 r.

13 S. Kamiński, Nauka i metoda. Pojęcie nauki i klasyfikacja nauk. Towarzystwo Naukowe Katolickiego Uniwersytetu Lubelskiego, Lublin 1992, p. 7.

14 T.S. Kuhn, Struktura rewolucji naukowych, tłum. H. Ostromęcka. Aletheia, Warszawa 2001, s. 304-305, s. 306; A. Pawłowski, Paradygmat. http://logic.amu.edu. 
During own work regarding paradigm, Kuhn modified his views, and eventually adopted the classic, semantic version of the paradigm, as a certain model, or pattern ${ }^{15}$. Therefore, as Marcin Kępa notices, by his modernised way of perceiving the paradigm, Kuhn raised the meaning of the basic concepts, such as pattern and model, therefore, of that which organised the scientific practices, and created thought schemes ${ }^{16}$.

Realising the development of thought regarding the understanding of the paradigm, as well as, that the issue is broadly discussed in the source literature by Amadeusz Krause ${ }^{17}$, for the sake of this article, we shall remain with the narrower understanding of the concept, assuming that this is the understanding useful in the social sciences ${ }^{18}$.

Within the framework of the indicated sciences, the methodological aspect of the paradigm received particular significance ${ }^{19}$. Giorgio Agamben ${ }^{20}$, directed his attention exactly at this understanding. The author thought that the paradigm is a hypothesis, or

pl/images/1/16/Paradygmat.pdf; Dostęp 11.04.2019 r. A. Pawłowski, Paradygmaty nowoczesności, 2014. Państwowa Galeria Sztuki w Sopocie, www. Paradygmat.pdf 14.04.2019 r.; M. Kępa, Metodologiczne ujęcie paradygmatu jako metody badawczej na przykładzie koncepcji Thomasa Kuhna, http://www.repozytorium.uni.wroc.pl/Con tent/66140/23_Mateusz_Kepa.pdf. Access: 14.04.2019 r.

15 T.S. Kuhn, Struktura rewolucji naukowych, (trans.) H. Ostromęcka. Aletheia, Warszawa 2001, cap. 5.

${ }^{16}$ M. Kępa, Metodologiczne ujęcie paradygmatu jako metody badawczej na przyktadzie koncepcji Thomasa Kuhna. http://www.repozytorium.uni.wroc.pl/Content/66140/ 23Mateusz_Kepa.pdf. Access: 14.04 .2019 r., p. 365.

${ }^{17}$ A. Krause, Wspótczesne paradygmaty pedagogiki specjalnej. Wydawnictwo Impuls, Kraków 2010.

${ }^{18}$ S. Kamiński, Nauka i metoda. Pojęcie nauki i klasyfikacja nauk. Towarzystwo Naukowe Katolickiego Uniwersytetu Lubelskiego, Lublin 1992, p. 174.

${ }^{19}$ A. Motycka, Relatywistyczna wizja nauki. Analiza krytyczna koncepcji T.S. Kuhna i S.E Toulmina. Wydawnictwo PAN, Wrocław 1980, p. 6; G. Musiał, Paradygmat, prawo nauki, rozwój spoteczny: ujęcie metodologiczne. Akademia Ekonomiczna, Katowice 1997, p. 12.

${ }^{20} \mathrm{G}$. Agamben, What is a paradigm?, 2002, http://www.egs.edu/faculty/gior gio-agamben/articles/what-is-a-paradigm. Access: 17.04.2019 r. 
a presupposition, that is more understandable in practice, which allows to determine its certain (previously not assumed) principles. According to Agamben, in numerous theoretical and historical studies, we are not dealing with a previously assumed object of research. Therefore, the object of the analyses may be determined, and presented by paradigms ${ }^{21}$. The methodological approach to the paradigm is also presented by Imre Lakatos22. The author writes that "when theory lags behind the facts, we are dealing with miserable degenerating research programmes... Thus, in a progressive research programme, theory leads to the discovery of hitherto unknown novel facts. In degenerating programmes, however, theories are fabricated only to accommodate known facts" 23 . Kuhn thinks in similar notes, writing, that a given paradigm functions, and is in motion until the occurrence of a crisis situation, caused by the inefficiency of a given scholarly tradition in the face of the appearing, new, unprecedented challenges. Then, during a time of an interparadigmatic transition period, a new paradigm is shaped, that sheds an entirely new light on the established scholarly tradition ${ }^{24}$.

Referring the presented content to special pedagogy, one may notice, that currently, we are dealing with the degeneration of scholarly programmes, i.a. related to the medical and social model of disability ${ }^{25}$. We remain in the inter-paradigmatic transition period,

${ }^{21}$ G. Agamben, What is a paradigm?, 2002, http://www.egs.edu/faculty/gior gio-agamben/articles/what-is-a-paradigm. Access: 17.04.2019 r.

22 I. Lakatos, Nauka i pseudonauka, (in:) I. Lakatos, Pisma z filozofii nauk empirycznych, (trans.) W. Sady. PWN, Warszawa 1995, pp. 360-361, p. 184 and others.

${ }^{23}$ I. Lakatos, Nauka i pseudonauka, (in:) I. Lakatos, Pisma z filozofii nauk empirycznych, (trans.) W. Sady. PWN, Warszawa 1995, pp. 360-361, p. 184 and others.; E. Piotrkowska, Społeczny konstruktywizm a matematyka. Wydawnictwo Naukowe UAM, Poznań 2008, p. 9.

${ }^{24}$ K. Jodkowski, Paradygmat. file:// / C:/Users/user/Desktop/Jodkowski_Para dygmat_1987.pdf, p. 460. Access: 12.04.2019 r.

25 I. Chrzanowska, Pedagogika specjalna. Od tradycji do nowoczesności, Impuls Kraków 2015, M. Chodkowska, Z. Kazanowski, Socjopedagogiczne konteksty postaw nauczycieli wobec edukacji integracyjnej, (in:) Z. Palak, Z. Bartkowicz (eds.) Wsparcie społeczne w rehabilitacji i resocjalizacji, Wydawnictwo Naukowe UMCS, Lublin 
in which new approaches towards disability appear. Here, we are talking about approaches, as, in contemporary scientific inquiry, we face less and less coherent models, more often, we deal with various scholarly approaches, positions, or analysis directions ${ }^{26}$.

\section{The reconfigurations of scientific and scholarly approaches}

In the 1990s, in social sciences, changes appeared, that were based on the critique of humanism, the departure from anthropocentrism, the emergence of a new materialism, redirecting the studies towards objects, animals, and relations between people, and non-people 27.

The critique of structuralism and poststructuralism was made visible. A clear departure from constructivism, popular since the 1970s, as it was deemed inadequate in regard to the current inquiries

2004, G. Drżałowska, Integracja edukacyjna a integracja społeczna, (in:) G. Drżałowska, H. Żuraw (eds.) Integracja społeczna osób niepełnosprawnych, Żak, Warszawa 2004, J. Głodkowska, Między integracją a izolacja- jedność w zróżnicowaniu a oddzielenie w odmienności, (in:) M. Orłowska (ed.) Skazani na wykluczenie, Wydawnictwo APS, Warszawa 2015, J. Kirenko, Oblicza niepetnosprawności, Wydawnictwo Akademickie WSSP, Lublin 2006, Cz. Kosakowski, Węzłowe problemy pedagogiki specjalnej, Akapit, Toruń 2003, M. Kościelska, Oblicza upośledzenia, PWN Warszawa 1995, A. Maciarz, Integracja społeczna niepetnosprawnych, WSiP, Warszawa 1987, D. Podgórska-Jachnik, Głusi. Emancypacje, WNWSP, Łódź 2013, T. Żółkowska, Wyrównywanie szans społecznych osób z niepetnosprawnością intelektualna, Inplus, Szczecin 2004.

${ }^{26}$ A. Krause, Wspótczesne paradygmaty pedagogiki specjalnej. Wydawnictwo Impuls, Kraków 2010.

${ }^{27}$ M. Bakke, Bio-transfiguracje. Sztuka i estetyka posthumanizmu. Wydawnictwo Naukowe UAM, Poznań 2010; J. Bednarek, Emancypacyjna obietnica posthumanizmu. Praktyka teoretyczna, 2014, 4(14), pp. 171-177; R. Braidotti, Po człowieku. Tłum. J. Bednarek, A. Kowalczyk. Wydawnictwo Naukowe PWN, Warszawa 2014. A. Kowalczyk, Wspólnota poszerzona - spotkania ludzkich i pozaludzkich aktorów. Praktyka Teoretyczna 2010, 1(1), pp. 94-115; K. Leszczyńska, K. Skowronek, Wolność i wierność. O roli zwrotów w humanistyce i naukach społecznych, (in:) K. Leszczyńska, K. Skowronek (eds.) Performatywne wymiary kultury. Wydawnictwo Libron, Kraków 2012. 
on the developing approach towards the subject, including materiality, bio-politics, etc. ${ }^{28}$.

According to Ewa Piotrowska, constructivism is not a coherent, consistent structure, and the scholarly methods, cognitive premises, and views, are manifested in various forms and versions. The author writes that no coherent epistemology is in motion here, and one may even notice a certain terminological and evaluative chaos ${ }^{29}$. Constructivism is an assortment of theories, approaches that are often characterised with borrowings from various cognitive sources, and displaying the influence of various scholarly orientations (postmodernist, structuralist, or poststructuralist). Obviously, the representatives of constructivism did not simply passively adopt various approaches that they found interesting; most often, they made changes, modifications, for the purpose of enriching the constructionist interpretation. What constructivists have in common is the search for the social principles of the genesis of the determinants of development of abstracted structures, as well as, of the influence and applications of science ${ }^{30}$.

Indicating the decreasing usefulness of constructivism, one cannot question the achievements of the trend, particularly its significance for the politicising of science. Constructivism is a significant emancipation movement, involved in social and political matters. It was, and still is characterised by political activity, and ideological involvement. It allowed the scholars to unmask the actions of the

${ }^{28}$ K. Barad, Posthumanistyczna performatywność: ku zrozumieniu, jak materia zaczyna mieć znaczenie, (in:) A. Gajewska (ed.), Teorie wywrotowe. Antologia przekładów. Wydawnictwo Poznańskie, Poznań 2012; Feministyczne nowe materializmy: usytuowane kartografie, O. Cielemęcka i M. Rogowska-Stangret (ed.), Lublin, https://www. academia.edu/36656598/Feministyczne_nowe_materializmy_usytuowane_kartogra fie. Access: 22.04.2019 r.; B. Kuźniarz, Goodbye Mr. Postmodernism. Teorie społeczne myślicieli późnej lewicy. Wydawnictwo Naukowe Uniwersytetu Mikołaja Kopernika, Toruń 2011.

${ }^{29}$ E. Piotrkowska, Społeczny konstruktywizm a matematyka. Wydawnictwo Naukowe UAM, Poznań 2008, p. 42.

30 E. Piotrkowska, Społeczny konstruktywizm a matematyka. Wydawnictwo Naukowe UAM, Poznań 2008, p. 9, 10. 
government, reveal the ways of constructing reality, the social situation of selected social groups, etc. Constructivism was, and still is, of an interdisciplinary nature. It was employed by ethnic studies, gender studies, as well as, disability studies ${ }^{31}$.

Currently, the departure from the constructivist interpretation is postulated by the advocates of posthumanism. Posthumanism is a term introduced by Ihab Hassan"32, who wrote that "the human form - including human desire and all its external representations may be changing radically, and thus must be revised. We need to understand that five hundred years of humanism may be coming to an end, as humanism transforms itself into something that we must helplessly call posthumanism ${ }^{33}$.

Posthumanism is one of the most significant theoretical directions of the turn of the $20^{\text {th }}$ and $21^{\text {st }}$ centuries. However, the "post" prefix does not mean breaking the connection with the humanist tradition, but indicates the need to take up a critique of humanism both from the external perspective, as well as, from the perspective of what is going on with humanism on the inside ${ }^{34}$. Cary Wolfe ${ }^{35}$,

31 B. Borowska-Beszta, Wkład antropologii kulturowej w studia nad niepetnosprawnością, Interdyscyplinarne Konteksty Pedagogiki Specjalnej, 15, 2016, I. Chrzanowska, Pedagogika specjalna. Od tradycji do wspótczesności, Impuls, Kraków 2015, Z. Gajdzica, Człowiek z niepetnosprawnością w rezerwacie przestrzeni publicznej, Wydawnictwo Impuls, Kraków 2013, S. Sadowska, Ku edukacji zorientowanej na zmiane społecznego obrazu osób niepetnosprawnych, Akapit, Torun 2005, A. Twardowski, Disability studies jako przykład interdyscyplinarnego podejścia do niepetnosprawności, maszynopis nieopublikowany, Poznań 2017, M. Wlazło, Interdyscyplinarne studia nad niepetnosprawnościa - sprzymierzeniec czy wróg pedagogiki specjalnej? Problemy Edukacji, Rehabilitacji i Socjalizacji Osób Niepełnosprawnych 23/2, pp. 65-74, 2016.

32 I. Hassan, Prometheus as Performer: Toward a Posthumanist Culture? Georgia Review 1977, Winter, vol. 31, no. 4, p. 843.

33 I. Hassan, Prometheus as Performer: Toward a Posthumanist Culture?, Georgia Review 1977, Winter, vol. 31, no. 4, p. 843; after; M. Bakke, Bio-transfiguracje. Sztuka i estetyka posthumanizmu, Wydawnictwo Naukowe UAM, Poznań 2012, pp. 18-19.

34 N. Badmington, Theorizing Posthumanizm, Cultural Critique 2003, Winter, no. 53 , p. 11 and next.

35 C. Wolfe, What is Posthumanism? University of Minnesota Press, Minneapolis 2010, file:// / C:/Users/user/Desktop/What\%20is\%20Posthumanizm.pdf. Access: 22.04.2019 r. 
for whom posthumanism is the search for modern (not rooted in humanism) ways of presenting subjectivity, of speaking about men, and other lifeforms, presents a similar opinion ${ }^{36}$. According to Wolfe, the essence is not, to depart from humanism entirely, but to develop a critical approach regarding the real contexts of the values considered as humanist: equality, tolerance, justice or liberty ${ }^{37}$. In posthumanism, another highlight is made, regarding the fact, that no artificial hierarchic divisions should be made, such as: nature/culture, $\mathrm{man} / \mathrm{machine}$, man/animal, etc. ${ }^{38}$. It is important to promote a postanthropocentric approach, and to spread the knowledge which critically refers to man assuming the central position within the universe.

Among the representatives of the critical approach to anthropocentrism, were, i.a. Michel Foucault, who proclaimed the "death of man"39, Jacques Derrida, who would write about the "end of man" 40 , or Francis Fukuyama who predicted "our posthuman future" 41 . The authors listed, indicated the new placement of man, the departure from apprehending man as the guarantee of values and sense ${ }^{42}$. They exposed the passing of a particular construct, that made place

36 C. Wolfe, What is Posthumanism? University of Minnesota Press, Minneapolis 2010, file:/ / / :/Users/user/Desktop/What\%20is\%20Posthumanizm.pdf, s. xvi. Access: 22.04.2019 r.

37 C. Wolfe, What is Posthumanism? University of Minnesota Press, Minneapolis 2010, file:/ / C:/Users/user/Desktop/What\%20is\%20Posthumanizm.pdf, s. xvi. Access: 22.04.2019 r.

${ }^{38}$ M. Bakke, Bio-transfiguracje. Sztuka i estetyka posthumanizmu. Wydawnictwo Naukowe UAM, Poznań 2010, p. 21.

${ }^{39}$ M. Foucault, Interview met Michel Foucault, Dits et Ecrist: 1954-1988, (in:) M. Loba, O śmierci podmiotu trzydzieści lat później, (in:) S. Wysłouch, B. Kaniewska (eds.), Człowiek i rzecz. O problemach reifikacji w literaturze, filozofii i sztuce. Poznańskie Studia Polonistyczne. Seria Literacka, Poznań 1999.

40 J. Derrida, Kres człowieka, (trans.) P. Piątek, (in:) B. Banasiak (ed.) J. Derrida, Pismo filozofii. Inter EssE Kraków 1993, p. 184.

${ }^{41} \mathrm{~F}$. Fukuyama, Koniec człowieka. Konsekwencje rewolucji biotechnologicznej, (trans.) B. Pietrzyk. Wydawnictwo Znak, Kraków 2005, p. 20.

${ }^{42} \mathrm{M}$. Loba, O śmierci podmiotu trzydzieści lat później, (in:) S. Wysłouch, B. Kaniewska (ed.), Człowiek $i$ rzecz. O problemach reifikacji w literaturze, filozofii $i$ sztuce. Poznańskie Studia Polonistyczne. Seria Literacka, Poznań 1999, p. 392. 
for a new model, referring to the common man, not entangled in great historical narratives, but a particular, geographically located, historically situated man, a man who is socially and politically transparent, who may be marginalised, excluded, and forgotten ${ }^{43}$. The new model of man, is also the posthuman, as described by Fukuyama. A construct built in result of the biotechnological revolution. Apparently, the drastic development of technology, dramatically affected the human condition ${ }^{44}$. Biopower, found its interest in life, life as it is, and the biopolitical curiosity, was transferred from the body discipline, and population regulating, described Foucault, to the life in its biological aspect ${ }^{45}$. Biopolitics is increasingly offensive (biometrics, birth control), and biotechnology provides us with newer and newer, genetically modified plants, animals, and even people.

The new model of the subject, is also a construct that questions the boundaries between people, and spreading visions about new human, and non-human relations, cross-species interdependencies apparent between men, animals, plants, objects, and technology. Bruno Latour writes about it, highlighting that the most important thing for the construction of a human subject, is to understand our constitutive relationality, that encompasses not only machines, but everything that is inanimate and non-human in general ${ }^{46}$. The issue

${ }^{43}$ G. Agamben, Homo Sacer. Suwerenna władza i nagie życie, (trans.) M. Salwa. Prószyński i S-ka, Warszawa 2008; M. Bakke, Bio-transfiguracje. Sztuka i estetyka posthumanizmu. Wydawnictwo Naukowe UAM, Poznań 2010; B. Latour, Nadzieja Pandory: eseje o rzeczywistości w studiach nad nauka, (trans.) K. Abriszewski. Wydawnictwo Naukowe Uniwersytety Mikołaja Kopernika, Toruń 2013, p. 247, 254 and others.

${ }^{44} \mathrm{~F}$. Fukuyama, Koniec człowieka. Konsekwencje rewolucji biotechnologicznej, (trans.) B. Pietrzyk. Wydawnictwo Znak, Kraków 2005.

45 R. Braidotti, Po człowieku, (trans.) J. Bednarek, A. Kowalczyk. Wydawnictwo Naukowe PWN, Warszawa 2014; M. Foucault, Historia seksualności, (trans.) B. Banasiak, T. Komendant, K. Matuszewski. Czytelnik, Warszawa, 1995, p. 122; J. Lejman, Człowiek a zwierzę. Biologiczne i kulturowe źródła antropocentryzmu, Wschodni Rocznik Humanistyczny, 2015, vol. XI.

46 B. Latour, Polityka natury, tłum. A. Czarnacka, M. Gdula. Wydawnictwo Krytyki Politycznej, Warszawa 2009. 
is taken up by Rosi Braidotti, proposing the reformulation of the human relations with the non-human relations. The author bases her inquiries on a materialist theory focused on the distinction between bios and $z o e^{47}$. Bios is the expression of life, of particular features, explicit, characteristic silhouette, that differentiates one being from the other. Zoe is the life of all living creatures, all indeterminate life, the biological aspect of $i^{48}$. Braidotti introduces zoe to the social theory, previously expelled from the humanist tradition, and visualises the possibility of reformulating the relations of humans and non-humans. She highlights that, the understanding of what lifeforms we are, and what are our interdependencies with other life forms, alone allows to connect zoe with bios. We saw, that the good life, i.e. bios, is the inherent element of our non-human (biological) lives ${ }^{49}$.

Therefore, the paradigmatic reconfiguration within the social theory, indicates new aims of generating knowledge, new contexts, and new points of reference. New research issues, and new interpretation frameworks appear. The matter is perceived differently, as, in the new scholarly approaches, it is dynamic, unplanned, nonintentional of the activity of coming-to-be. The new materialism stood in opposition to constructivism, as, without eliminating the social aspect of knowledge, and not striving towards essentialism, it simply created material determinants. In the new approach regarding matter, notions are made about the necessity of the "communisation" of nature. For nature is created both by humans and by non-humans. Donna Haraway writes, that we must finally realise, that not all actors are us, as not all of them are human, not all are organic, and not all are technological ${ }^{50}$.

47 R. Braidotti, Po człowieku, (trans.) J. Bednarek, A. Kowalczyk. Wydawnictwo Naukowe PWN, Warszawa 2014.

${ }^{48}$ K. Kerenyi, Dionizos. Archetyp życia niezniszczalnego, (trans.) I. Kania. Wydawnictwo Baran i Suszczyński, Kraków 1997, p. 16.

${ }^{49}$ R. Braidotti, Po człowieku, (ed.) J. Bednarek, A. Kowalczyk. Wydawnictwo Naukowe PWN, Warszawa 2014.

50 D. Haraway, The Promises of Monsters. A Regenerative Politics for Inappropriate/d Others, (in:) D. Haraway (ed.), The Haraway Reader, Routledge 2004, p. 105. 
According to Łodyga and Włodarczyk, posthumanism is an approach of a polyphonic nature, and is not dedicated to the obsessed defining of own limits, and postulating a crisis of humanity, but it proposes a broad range of hermeneutic positions, from the perspective of which, we may anew conduct an overview of the complicated relations of animals, humans, nature, technology, and the borderline between the animate and the inanimate worlds ${ }^{51}$.

\section{Towards a new model of disability}

The examples of the posthumanist approaches that may determine the context for creating new models of disability, are, i.a.: the Actor-Network theory by Bruno Latour and associates ${ }^{52}$, Deleuze and Guattari's Rhizomatic theory 53 or the nomadic theory by Rosi Braidotti ${ }^{54}$. The following article will be limited only to the first of the listed theories.

The Actor-Network Theory (ANT), developed by Bruno Latour, Michel Callon, and John Law ${ }^{55}$ is based on posthumanist premises. According to Michał Wróblewski, it constitutes a very useful tool, that displays ambitions of more than just another theory that explains some phenomenon of modern science ${ }^{56}$.

${ }^{51}$ Z. Łodyga, J. Włodarczyk, Wstep, (in:) Z. Łodyga, J. Włodarczyk (eds.) Po humanizmie. Od technokrytyki do animals studies. Wydawnictwo Naukowe Katedra, Gdańsk 2015, p. 15.

${ }^{52} \mathrm{~K}$. Arbiszewski, Wszystko otware na nowo. Teoria Aktora-Sieci i filozofia kultury. Wydawnictwo Naukowe Uniwersytetu Mikołaja Kopernika, Torun 2010.

${ }^{53}$ G. Deleuze, F. Guattari, Kłacze, (trans.) B. Banasik. Colloquia Communia 1988, no. 1-3.

${ }^{54}$ R. Braidotti, Podmioty nomadyczne. Ucieleśnienie i różnica seksualna w feminizmie wspótczesnym, tłum. A. Derra. Wydawnictwo Akademickie i Profesjonalne, Warszawa 2009.

${ }^{55} \mathrm{~K}$. Arbiszewski, Wszystko otware na nowo. Teoria Aktora-Sieci i filozofia kultury. Wydawnictwo Naukowe Uniwersytetu Mikołaja Kopernika, Toruń 2010, p. 18.

${ }^{56} \mathrm{M}$. Wróblewski, Choroba jako hybryda. ADHD w świetle Teorii Aktora-Sieci i Asocjologii, Studia Socjologiczne, 2011, no. 4, p. 125. 
ANT is a scholarly position, that introduced a number of interesting premises to social sciences, and inquiries regarding the reconfiguration of the models of disability ${ }^{57}$. First, it allows for an analysis of a given phenomenon, in terms broader than within a given discipline. In regard to disability, it may be interdisciplinary studies (psychological, sociological, medical), as well as, those seemingly not related to disabilities at all, such as: political, legal, pharmacological, as well as, analyses from the areas of digital technologies, employers interests, or the benefits of persons with disabilities. Second, by applying ANT, one may verify the existing information regarding disabilities. g.g. those related to diagnosis, the understanding of the concept, classification, or therapy. However, it is not simply another description of an actual situation, but the cognition and the analysis of the factors, that shape and maintain given information. ANT allows to see many, even more subtle, legal, institutional, or economic displacements that may aid in changing the existing model of disability. Third, ANT postulates the transformation in apprehending the social phenomenon itself, i.e. - in the case that is interesting to us - the phenomenon of disability. It means, to transfer from the vertical to the horizontal plane, and to introduce the entangled relations, webs, or networks. In ANT, the vertical overview of reality, is subject to the posthumanist, horizontal theories of this reality, the horizontal way of reading the situation of the human, and his relations to non-humans ${ }^{58}$. The horizontal model means to conduct extensive research, comparisons aiming at distinguishing the common ground for mediation for both humans, and non-humans. The vertical model in turn, is a profound case study ${ }^{59}$. Piotr Sadzik thinks, that the introduction of horizontal

${ }_{57}$ M. Wróblewski, Choroba jako hybryda. ADHD w świetle Teorii Aktora-Sieci i Asocjologii, Studia Socjologiczne, 2011, no. 4, pp. 122-153.

58 J. Dolińska, Sieci relacji a sidła opisu, (in:) Z. Ładyga, J. Włodarczyk (eds.), Po humanizmie. Od technokrytyki do Animal Studies, Wydawnictwo Naukowe Katedra, Gdańsk 2015.

${ }^{59}$ M. Bakke, Bio -transfiguracje. Sztuka i estetyka posthumanizmu, Wydawnictwo Naukowe UAM, Poznań 2012. 
orientations was a sign of rebellion, the resistance of posthumanism, against all (not only capitalist) forms of exploitation, and the call to build relations, that would depart from vertical relations (of power), for the sake of horizontal relations (of solidarity) ${ }^{60}$. Considering disability, from a vertical position related to power and otherness, may be helpful in unmasking selected approaches. The approaches, that Zizek describes as follows - a hierarchical thinking resulting from human arrogance, and anthropocentric premises, is violence against the other ${ }^{61}$. Derrida has a similar opinion, highlighting, that posthumanism shapes the political critique of harm done to various others, by the Western (humanistic) ${ }^{62}$. Braidotti writes in a similar sense, indicating that, the internal motor of the humanistic power of man, who turned the definition of difference on a hierarchical scale, into an instrument of governance, is the dialectics of otherness... All those "others", as a negative, pathological deviation from norm, are sent to the domain of anomaly, deviation, monstrosity, and animality. The vertical approach towards disability may unmask the subjection of disability to economic factors, global control networks, and turning the persons with disabilities, along with their families, subordinate to market economy in all areas of personal and social functioning ${ }^{63}$.Vertical orientation, also reflects the specie hierarchy that shows in the dominance of the persons with disabilities, over all non-human subjects, however, dependence on human subjects in the majority of spheres of functioning 64 . Additionally, the vertical approach towards disability, allows to see the significance of the social and political hierarchy, influencing the terminology, the clas-

60 P. Sadzik, Nie-ludzka wspólnota równych, Praktyka Teoretyczna no. 4(14), 2014.

61 S. Zizek, Przemoc. Sześć spojrzeń z ukosa, (trans.) A. Górny, Warszawskie Wydawnictwo Literackie Muza, Warszawa 2010.

62 J. Derrida, Is There a Philosophical Language?, (in:) L. Thomassen (ed.), The Derrida-Habermas Reader, Univesity Edinburgh, Edinburgh 2006.

${ }^{63}$ R. Braidotti, Po Człowieku, tłum. J. Bednarek, A. Kowalczyk, PWN, Warszawa 2010.

${ }^{64}$ M. Bakke, Bio -transfiguracje. Sztuka i estetyka posthumanizmu, Wydawnictwo Naukowe UAM, Poznań 2012. 
sifications of disability, rehabilitation, the quality of life of the persons with disabilities, as well as, their social situation (marginalisation and exclusion). It also shows the significance of the scientific and economic hierarchy - where the ways of defining and classifying (e.g. DSM, ICD), serve as the basis for the selection of a therapy, which in turn, is a source of profit for a wide range of various specialists. The broadest significance of the vertical perspective is presented by Donna Haraway, writing that in a hierarchical system "Our authenticity is warranted by a database for the human genome. The molecular database is held in an informational database as legally branded intellectual property in a national laboratory with the mandate to make the text publicly available for the progress of science and advancement of industry. This is Man the taxonomic type become Man the brand" 65 .

In turn, the considerations regarding the models of disability, taken from a horisontal position, refer to the mutual relations and connections that appear in the world of life. ANT is based on postconstructivist premises, it removes the epistemological relation, constitutive for constructivism, and replaces it with relational ontology. In a relational ontology, relation of transformation and affecting is key ${ }^{66}$. According to Latour, constructing is not just social, it is a multidimensional process, often material and technical, occurring after the civilisation changes of the modern world, including the scientific and technological achievements. Latour gives examples of the constructed object, such as, i.a. radios, clocks, political

65 D. Haraway, Modest Witness @ Second_Millenium. FamaleMan_Meets_Onco_ Mause, London-New York 1997, p. 74.

${ }^{66} \mathrm{~K}$. Arbiszewski, Wszystko otware na nowo. Teoria Aktora-Sieci i filozofia kultury. Wydawnictwo Naukowe Uniwersytetu Mikołaja Kopernika, Torun 2010, p. 18; E. Bińczyk, Praktyka, laboratorium, czynniki pozaludzkie. Najnowsze modele technonauki oraz wybrane tezy Ludwika Flecka, 2009, http://fleck.umcs.lublin.pl/teksty.htm, Access: 15.04.2019 r.; T. Sikora, Odmieńcy / śmieci. Kultura Wspótczesna. Teorie. Interpretacje. Praktyka 2007, no. 4(54), pp. 45-62; A. Zybertowicz, Przemoc i poznanie. Studium z nie-klasycznej socjologii wiedzy. Wydawnictwo Naukowe Uniwersytetu Mikołaja Kopernika, Torun 2005. 
programmes, but also, the ozone hole, frozen embryos, data banks, or viruses ${ }^{67}$. Based on Latour's theses, one may indicate, that, in constructing the model of disability, one should consider the relations determined by the network, relations of elements that vary ontologically, including social relations and non-human factors. To conceptualise disability from the ANT perspective, one must see three elements: material, conceptual, and normative, or organisational ${ }^{68}$. In other words, the model of disability may be described by the relations occurring between people, things (e.g. rehabilitation equipment), scientific theories, institutions (school, social service centre), animals (e.g. a guide dog), the casual perception of the phenomenon, textbooks, procedures at the workplace, law, other persons with disabilities, expectations from the local communities, everyday items (cutlery, furniture), architectonic concepts, interests of the companies that produce the rehabilitation equipment, etc. Fourth, ANT grasps the objects and the collectivities through the prism of difference. Each human - being, has own identity that is an effect of his relation with other actors. ANT introduces relational ontology to replace essentialism. Beings have their identity not because of essential features (however they are not omitted), but due to their relations to other beings. The relations, differences, and their change, retain the primacy in the ontological plane, however, the essences are a result of establishing and stabilising a certain portion of a relation ${ }^{69}$. The key attribute is the fact, that the network is a result of the relations between various beings, the strength of these connections being the most important. Strong connections are based on the result of scientific studies, or law, therefore, the areas that provide authority, and give strong, stable fixing that is not

67 B. Latour, Nigdy nie byliśmy nowocześni. Studium z antropologii symetrycznej, (trans.) M. Gdula. Oficyna Naukowa, Warszawa 2011, p. 49 and others.

68 B. Latour, Polityka natury, (trans.) A. Czarnacka, M. Gdula. Wydawnictwo Krytyki Politycznej, Warszawa 2009.

${ }^{69}$ K. Arbiszewski, Wszystko otware na nowo. Teoria Aktora-Sieci i filozofia kultury. Wydawnictwo Naukowe Uniwersytetu Mikołaja Kopernika, Toruń 2010. 
questioned ${ }^{70}$. According to Latour, the actors create the hybrid connection networks the entire time, and they are "simultaneously real, like nature, narrated, like discourse"

Using the above premises for the construction of the model of disability, one may state, that ANT allows to see that every man each person with a disability, has an identity defined by their relations with other humans and non-humans, is someone else, and differs from others. The person is defined by relations and beams of relations that appear in spheres such as biological, social and cultural, normative, material and organisational, scientific, practical, etc. Within the model of disability, it would be advisable to assume, that disability is a social phenomenon, a biological fact, coming into medical (diagnosis, treatment), and psychological (diagnosis, therapy) relations, the controversies about the causes of the disability, the casual knowledge regarding behaviour, scientific theories, textbooks, the interest of the medicine producers, attitudes in the natural environment, the interest from the media, the interests of professionals, school didactic aid, the theories of social participation, law, etc. Disability within the ANT approach, will be a phenomenon of hybrid-like nature, as an issue of science, medicine, law, politics, and institutions. Hybrid, as translation networks, that work, transform, and affect the social life ${ }^{72}$. Translation is such a relation between two elements, that transforms them. Disability will be an assortment of elements, where each of them plays a constitutive role regarding the whole, co-creates it and determines the actions regarding other phenomena. These would be as follows: a scientific theory, therapy workshops, disability classification, etc. Each ele-

${ }^{70}$ K. Arbiszewski, Wszystko otware na nowo. Teoria Aktora-Sieci i filozofia kultury. Wydawnictwo Naukowe Uniwersytetu Mikołaja Kopernika, Torun 2010, M. Wróblewski, Choroba jako hybryda. ADHD w świetle Teorii Aktora-Sieci i Asocjologii, Studia Socjologiczne 2011, no. 4, p. 127.

71 B. Latour, Nigdy nie byliśmy nowocześni. Studium z antropologii symetrycznej, (trans.) M. Gdula. Oficyna Naukowa, Warszawa 2011.

72 B. Latour, Nigdy nie byliśmy nowocześni. Studium z antropologii symetrycznej, (trans.) M. Gdula. Oficyna Naukowa, Warszawa 2011. 
ment has its own way of working, of conceptualising the world, and of exercising influence ${ }^{73}$. Hybrids may combine humans, social institutions, scientific research, discourses, etc. Therefore, the application of ANT gives the possibility of a precise description of the relations that shape, and maintain the models of disability. Adopting the premise about the hybrid nature of disability allows to consider the knowledge from various other scientific disciplines, from various material, social, organisational areas, etc. Creating the model of disability, it is important to not, that the translation networks are created due to the reception of data, and combining it in search of new regularities. As noted by Michał Wróblewski, that means that, from one set of elements, numerous wholes may be created, every time we emphasise differently, and explicate different elements. Writing a text is the same thing as weaving a network ${ }^{74}$.

Fifth, a question may be important for the new model of disability: How is it, that despite the heterogeneousness of the elements that refer to disability, there is a coherence and a stability of the network, like in the case of the departing medical paradigm? Michal Wróblewski writes, that maybe, the causes of the coherence, stability, and the translation character, should be found in the localisation of these networks in objectivised areas such as law or science. According to the author, the area of law and administrative institutions, activates the lawyers, politicians, administrators, and, simultaneously by delegating particular values, the legal procedures and administration acts, that legitimise the coherence and the stability of the translation network. In the case of disability, the network is constituted by the following elements: doctors, psychologists, scholars that prepare textbooks; and, from the non-human side, the textbooks, laboratories, along with all the technical apparatus, psychological clinic along with psychometric instruments. One cannot un-

${ }^{73}$ M. Wróblewski, Choroba jako hybryda. ADHD w świetle Teorii Aktora-Sieci i Asocjologii, Studia Socjologiczne 2011, no. 4, p. 127.

${ }_{74}$ M. Wróblewski, Choroba jako hybryda. ADHD w świetle Teorii Aktora-Sieci i Asocjologii, Studia Socjologiczne 2011, no. 4, pp. 121-154. 
derestimate the role of genes, the brain, as well as, cultural norms. At the level of therapy, the elements will be as follows: doctors, psychologists, pedagogues; and from the non-human side: textbooks, theories, medicine, rehabilitation room along with the entire equipment, the computer, biopolitics, etc. Wróblewski indicates, that each of the listed elements is characterised by a certain kind of effective impact, which cannot be reduced to a single meta-type. As the activity of the doctor cannot be compared to the work of a lawyer, or the effective impact of the psychology textbook. However, they all constitute a coherent translation network being the model of disability ${ }^{75}$. Sixth the advantage of ANT in building the models of disability, is, additionally, creating the framework for examining this phenomenon in controversial situations such as: genetic modifications, diet (e.g. in selected groups of disorders), vaccinations, antibiotics, necropolitics, biopower, etc. According to Latour, ANT allows to grasp, describe, and interpret these controversies ${ }^{76}$. As Binczyk notes, the cause of these controversies is the fact, that science does no give us certainty, and does not provide clear answers. In consequence, men must face contradictory expertises, economical and social interests, and opposed scientific theories ${ }^{77}$. Latour notes that economic and political interests have an impact on the formation of various phenomena in the current times dominated by globalisation and free-market economy. ANT shows and examines controversies, as they provide knowledge regarding subject that are uncertain and conflicting. They are contrary to continuity and stability. According to Latour we should get accustomed with controversy, because the complexity of the world will increase continually.

${ }^{75}$ M. Wróblewski, Choroba jako hybryda. ADHD w świetle Teorii Aktora-Sieci i Asocjologii, Studia Socjologiczne 2011, no. 4, pp. 134-135.

76 B. Latour, Polityka natury, (eds.) A. Czarnacka, M. Gdula. Wydawnictwo Krytyki Politycznej, Warszawa 2009.

77 E. Bińczyk, Praktyka, laboratorium, czynniki pozaludzkie. Najnowsze modele technonauki oraz wybrane tezy Ludwika Flecka, 2009, http://fleck.umcs.lublin.pl/teksty.htm, Access: 15.04.2019 r. 
No expertise will allow us to save ourselves from a situation of uncertainty and risk, as the complexity and the global nature of the interdependencies extends far beyond our capabilities of a cognitive overview $^{78}$. Latour highlights, that controversies are the "essential resource to render the social connections traceable"79. Following the traces of controversies aims at re-analyse the previously indicated connections, but now each element would be considered in a broader context, and with the aid of a larger group of acting ones ${ }^{80}$. In the case of the model of disability, ANT may help finding various controversies. For example, it may indicate the meaning of nonprogressive changes in defining the entire phenomenon. It may expose the economical and political interests, that affect the textbooks for diagnostics. ANT gives the ability to indicate numerous controversies regarding the etiology and the nature of disability. For ANT, there are no obstacles in analysing controversies regarding pharmacological substances, e.g. by juxtaposing the views presented by pharmacological companies, and scientists that present a different opinion. ANT may help in identifying the behind-the-scenes actions of groups, lobbying for beneficial legal and economic solutions, as well as, signal the abuse of the current regulations ${ }^{81}$.

To summarise, the selected premises, presented above, for the inquiries regarding the reconfiguration of the models of disability, one must indicate, that ANT may become a helpful instrument ${ }^{82}$. It is a scholarly orientation allowing to see that disability: a) may be considered as a hybrid, that combines factors such as the scientific,

78 B. Latour, Polityka natury, (eds.) A. Czarnacka, M. Gdula. Wydawnictwo Krytyki Politycznej, Warszawa 2009, p. 280.

79 B. Latour, Splatając na nowo, to co społeczne. Wprowadzenie do teorii aktora-sieci, (trans.) A. Derra, K. Arbiszewski. Universitas, Kraków 2010, p. 44.

${ }^{80}$ M. Wróblewski, Choroba jako hybryda. ADHD w świetle Teorii Aktora-Sieci i Asocjologii, Studia Socjologiczne 2011, no. 4, p. 136.

${ }^{81} \mathrm{M}$. Wróblewski, Choroba jako hybryda. ADHD w świetle Teorii Aktora-Sieci i Asocjologii, Studia Socjologiczne 2011, no. 4, p. 137.

82 M. Wróblewski, Choroba jako hybryda. ADHD w świetle Teorii Aktora-Sieci i Asocjologii, Studia Socjologiczne 2011, no. 4, p. 134. 
medical, legal, political, etc., b) it may be constructed by coherent and stable (rooted in science, and in law), translation networks, that combine scientific studies, people, social institutions, discourses, and law, that affect, transform and influence the phenomenon of disability, c) may be described with precision, by the relations and factors that shape and maintain the current models of disability, d) is constituted by heterogeneous elements, that have significant meaning for the whole, constitute it and indicate the actions regarding other phenomena, e) may be described with the use of a new language, with the use of terms such as: networks, relations, lines, relationships, dependencies, beams, translations, technoscience, etc $^{83}, \mathrm{f}$ ) may be defined on the basis of numerous humans and nonhumans. In relation to etiology, it will be the following: medical studies, laboratories, scientific theories, doctors, medical equipment, textbooks, etc. In the scope of the diagnosis the following will appear: specialists, textbooks, animals, clinics, legal procedures, etc. Constructing the model of disability, one must notice, that ANT is not a theory in the strict sense, but a certain methodological perspective. Its important premise, is the awareness, that an entire assortment of heterogeneous factors determine the specifics of a given social phenomenon ${ }^{84}$. ANT offers an assortment of directives and models, aiding in studying the world in a new, more comprehensive way ${ }^{85}$. It determines the methodological pointers, allowing the present the complexity of a phenomenon, as well as, its heterogeneous character.

${ }^{83}$ R. Braidotti, Podmioty nomadyczne. Ucieleśnienie i różnica seksualna w feminizmie wspótczesnym, tłum. A. Derra. Wydawnictwo Akademickie i Profesjonalne, Warszawa 2009; G. Deleuze, F. Guattari, Kłacze, tłum. B. Banasik. Colloquia Communia 1988, no. 1-3; B. Latour, Polityka natury, tłum. A. Czarnacka, M. Gdula. Wydawnictwo Krytyki Politycznej, Warszawa 2009.

84 B. Latour, Splatając na nowo, to co społeczne. Wprowadzenie do teorii aktora-sieci, (trans.) A. Derra, K. Arbiszewski. Universitas, Kraków 2010, pp. 89-122.

85 B. Latour, Polityka natury, (trans.) A. Czarnacka, M. Gdula. Wydawnictwo Krytyki Politycznej, Warszawa 2009. 


\section{Summary}

Regardless of, which research and scholarly perspective we will employ, in building a model of disability, no doubt, the issues of disability are an essential element of the posthumanist afterthought.

Currently, the posthumanist approach is not a coherent theory, and, at least for now, is more recognised by its characteristic attributes, i.a.: antianthropocentrism, ecology, biotechnology, posthuman, non-human, etc. However, the dynamics of the development, the values that it introduces, the ontologies it employs, the epistemologies it creates, and the methodologies it adopts, indicates, that the posthumanist approach, is an announcement of a new paradigm. A paradigm directed at the human, his environment perceived in broad strokes, and the community-oriented forms of life. Within the paradigm, man experiences interpersonal and inter-species connections, connections with nature and with the community. He also has the feeling of safety, of belonging, but also - of independence. Additionally, the new paradigm is an important instrument of ethics, here - the ethics of care, the ethics of solidarity, respect, and mutuality ${ }^{86}$.

The increased interest in posthumanism, and conducting research from this perspective, seems entirely justified both scientifically and practically. Posthumanism may contribute to the better understanding of the issues of disabilities, and have an impact on the social debate on the subject, and, particularly, on building a contemporary model of disability.

\section{Bibliography}

Agamben G., Homo Sacer. Suwerenna władza i nagie życie, (trans.) M. Salwa. Prószyński i S-ka, Warszawa 2008.

86 R. Braidotti, Po człowieku, (trans.) J. Bednarek, A. Kowalczyk. Wydawnictwo Naukowe PWN, Warszawa 2014. 
Agamben G., What is a paradigm?, 2002, http://www.egs.edu/faculty/giorgioagamben/articles/what-is-a-paradigm. Access: $17.04 .2019 \mathrm{r}$.

Arbiszewski K., Wszystko otware na nowo. Teoria Aktora-Sieci i filozofia kultury. Wydawnictwo Naukowe Uniwersytetu Mikołaja Kopernika, Torun 2010.

Badmington N., Theorizing Posthumanizm, Cultural Critique 2003, Winter, no. 53.

Bakke M., Bio-transfiguracje. Sztuka i estetyka posthumanizmu. Wydawnictwo Naukowe UAM, Poznań 2010.

Barad K., Posthumanistyczna performatywność: ku zrozumieniu, jak materia zaczyna mieć znaczenie, (in:) A. Gajewska (ed.), Teorie wywrotowe. Antologia przekładów. Wydawnictwo Poznańskie, Poznań 2001.

Bednarek J., Emancypacyjna obietnica posthumanizmu. Praktyka teoretyczna, 2014, 4(14).

Bińczyk E., Praktyka, laboratorium, czynniki pozaludzkie. Najnowsze modele technonauki oraz wybrane tezy Ludwika Flecka, 2009, http://fleck.umcs.lublin.pl/teksty.htm, Access: 15.04.2019 r.

Bobrowski I., Zaproszenie do językoznawstwa. Wydawnictwo Instytutu Języka Polskiego PAN, Kraków 1998.

Borowska-Beszta B., Wkład antropologii kulturowej w studia nad niepetnosprawnościa, Interdyscyplinarne Konteksty Pedagogiki Specjalnej, 15, 2016.

Braidotti R., Po człowieku, (trans.) J. Bednarek, A. Kowalczyk. Wydawnictwo Naukowe PWN, Warszawa 2014.

Braidotti R., Podmioty nomadyczne. Ucieleśnienie i różnica seksualna w feminizmie wspótczesnym, (trans.) A. Derra. Wydawnictwo Akademickie i Profesjonalne, Warszawa 2009.

Chodkowska M., Kazanowski Z., Socjopedagogiczne konteksty postaw nauczycieli wobec edukacji integracyjnej, (in:) Z. Palak, Z. Bartkowicz (eds.), Wsparcie społeczne w rehabilitacji i resocjalizacji, Wydawnictwo Naukowe UMCS, Lublin 2004.

Chrzanowska I., Pedagogika specjalna. Od tradycji do wspótczesności, Impuls, Kraków 2015.

Chrzanowska I., Pedagogika specjalna. Od tradycji do nowoczesności, Impuls Kraków 2015.

Deleuze G., Guattari F., Kłącze, (trans.) B. Banasik. Colloquia Communia 1988, no. 1-3.

Derrida J., Is There a Philosophical Language?, (in:) L. Thomassen (ed.), The DerridaHabermas Reader, Univesity Edinburgh, Edinburgh 2006.

Derrida J., Kres człowieka, (trans.) P. Piątek, (in:) B. Banasiak (ed.), J. Derrida, Pismo filozofii. Inter EssE Kraków 1993.

Dolińska J., Sieci relacji a sidła opisu, (in:) Z. Ładyga, J. Włodarczyk (eds.), Po humanizmie. Od technokrytyki do Animal Studies, Wydawnictwo Naukowe Katedra, Gdańsk 2015.

Drżałowska G., Integracja edukacyjna a integracja społeczna, (in:) G. Drżałowska, H. Żuraw (eds.) Integracja społeczna osób niepełnosprawnych, Żak, Warszawa 2004. 
Feministyczne nowe materializmy: usytuowane kartografie, (eds.) O. Cielemęcka, M. Rogowska-Stangret, E-Naukowiec, Lublin, 2018. https://www.academia. edu/36656598/Feministyczne_nowe_materializmy_usytuowane_kartografie. Access: 22.04.2019 r.

Foucault M., Historia seksualności, (trans.) B. Banasiak, T. Komendant, K. Matuszewski. Czytelnik, Warszawa 1995.

Foucault M., Interview met Michel Foucault, Dits et Ecrist: 1954-198, (in:) M. Loba, O śmierci podmiotu trzydzieści lat później, (in:) S. Wysłouch, B. Kaniewska (eds.), Cztowiek i rzecz. O problemach reifikacji w literaturze, filozofii i sztuce, Poznańskie Studia Polonistyczne. Seria Literacka, Poznań 1999.

Fukuyama F., Koniec człowieka. Konsekwencje rewolucji biotechnologicznej, (trans.) B. Pietrzyk. Wydawnictwo Znak, Kraków 2005.

Gajdzica Z., Człowiek $z$ niepetnosprawnościa w rezerwacie przestrzeni publicznej, Wydawnictwo Impuls, Kraków 2013.

Głodkowska J., Między integracją a izolacja- jedność w zróżnicowaniu a oddzielenie w odmienności, (in:) M. Orłowska (ed.) Skazani na wykluczenie, Wydawnictwo APS, Warszawa 2015.

Gurtowski S., Należeć do wszechświata. Poszukiwania na pograniczu nauki i duchowości, Collectanea Theologica, 1966, 66(4), pp. 207-211.

Haraway D., Modest Witness @ Second_Millenium. FamaleMan_Meets_Onco_Mause, London-New York 1997, p. 74.

Haraway D., The Promises of Monsters. A Regenerative Politics for Inappropriate/d Others, (in:) D. Haraway (ed.), The Haraway Reader, Routledge 2004.

Hassan I., Prometheus as Performer: Toward a Posthumanist Culture? Georgia Review 1977, Winter, vol. 31, no. 4.

Hassan I.,Prometheus as Performer: Toward a Posthumanist Culture? Georgia Review 1977, Winter, vol. 31, no. 4, s. 843; after; M. Bakke, Bio-transfiguracje. Sztuka i estetyka posthumanizmu, Wydawnictwo Naukowe UAM, Poznań 2012.

Jodkowski J., Paradygmat. file:///C:/Users/user/Desktop/Jodkowski_Paradygmat_ 1987.pdf. Access: 12.04 .2019 r.

Kamiński S., Nauka i metoda. Pojęcie nauki i klasyfikacja nauk. Towarzystwo Naukowe Katolickiego Uniwersytetu Lubelskiego, Lublin 1992.

Kerenyi K., Dionizos. Archetyp życia niezniszczalnego, (trans.) I. Kania. Wydawnictwo Baran i Suszczyński, Kraków 1997.

Kępa M., Metodologiczne ujęcie paradygmatu jako metody badawczej na przykładzie koncepcji Thomasa Kuhna. E-Wydawnictwo. Prawnicza i Ekonomiczna Biblioteka Cyfrowa, Wrocław 2015. http://www.repozytorium.uni.wroc.pl/Content/66 140/23Mateusz_Kepa.pdf. Access: 14.04.2019 r.

Kirenko J., Oblicza niepetnosprawności, Wydawnictwo Akademickie WSSP, Lublin 2006.

Kosakowski Cz., Węztowe problemy pedagogiki specjalnej, Akapit, Torun 2003. 
Kościelska M., Oblicza upośledzenia, PWN Warszawa 1995.

Kowalczyk A., Wspólnota poszerzona - spotkania ludzkich i pozaludzkich aktorów. Praktyka Teoretyczna 2010,1(1), pp. 94-115.

Krause A., Wspótczesne paradygmaty pedagogiki specjalnej. Wydawnictwo Impuls, Kraków 2010.

Kuhn T.S., Struktura rewolucji naukowych, (trans.) H. Ostromęcka. Aletheia, Warszawa 2001.

Kuźniarz B., Goodbye Mr. Postmodernism. Teorie społeczne myślicieli późnej lewicy. Wydawnictwo Naukowe Uniwersytetu Mikołaja Kopernika, Toruń 2011.

Lakatos I., Nauka i pseudonauka, (in:) I. Lakatos, Pisma z filozofii nauk empirycznych, tłum. W. Sady. PWN, Warszawa 1995, pp. 360-361.

Latour B., Nadzieja Pandory: eseje o rzeczywistości w studiach nad nauka, (trans.) K. Abriszewski. Wydawnictwo Naukowe Uniwersytety Mikołaja Kopernika, Toruń 2013.

Latour B., Nigdy nie byliśmy nowocześni. Studium z antropologii symetrycznej, (trans.) M. Gdula. Oficyna Naukowa, Warszawa 2011.

Latour B., Polityka natury, (trans.) A. Czarnacka, M. Gdula. Wydawnictwo Krytyki Politycznej, Warszawa 2009.

Latour B., Splatając na nowo, to co społeczne. Wprowadzenie do teorii aktora-sieci, (trans.) A. Derra, K. Arbiszewski. Universitas, Kraków 2010.

Lejman J., Człowiek a zwierze. Biologiczne $i$ kulturowe źródta antropocentryzmu, Wschodni Rocznik Humanistyczny, 2015, vol. XI.

Leszczyńska K., Skowronek K., Wolność i wierność. O roli zwrotów w humanistyce i naukach społecznych, (in:) K. Leszczyńska, K. Skowronek (eds.), Performatywne wymiary kultury. Wydawnictwo Libron, Kraków 2012.

Loba M., O śmierci podmiotu trzydzieści lat później, (in:) S. Wysłouch, B. Kaniewska (eds.), Człowiek $i$ rzecz. O problemach reifikacji w literaturze, filozofii i sztuce. Poznańskie Studia Polonistyczne. Seria Literacka, Poznań 1999.

Łodyga Z., Włodarczyk J., Wstęp, (in:) Z. Łodyga, J. Włodarczyk (eds.) Po humanizmie. Od technokrytyki do animals studies. Wydawnictwo Naukowe Katedra, Gdańsk 2015.

Maciarz A., Integracja społeczna niepetnosprawnych, WSiP, Warszawa 1987.

Motycka A., Relatywistyczna wizja nauki. Analiza krytyczna koncepcji T.S Kuhna i S.E Toulmina. Wydawnictwo PAN, Wrocław 1980.

Musiał G., Paradygmat, prawo nauki, rozwój społeczny: ujęcie metodologiczne. Akademia Ekonomiczna, Katowice 1997.

Pawłowski A., Paradygmat. http://logic.amu.edu.pl/images/1/16/Paradygmat.pdf; Access: 11.04.2019 r.

Pawłowski A., Paradygmaty nowoczesności, Państwowa Galeria Sztuki, Sopot 2014, www. Paradygmat.pdf Access: 14.04.2019 r. 
Piotrkowska E., Społeczny konstruktywizm a matematyka. Wydawnictwo Naukowe UAM, Poznań 2008.

Podgórska-Jachnik D., Głusi. Emancypacje, WNWSP, Łódź 2013.

Rainko S., Dwa paradygmaty. Państwowy Instytut Wydawniczy, Warszawa 2011.

Sadowska S., Ku edukacji zorientowanej na zmianę społecznego obrazu osób niepełnosprawnych, Akapit, Torun 2005.

Sadzik P., Nie-ludzka wspólnota równych, Praktyka Teoretyczna no. 4(14), 2014.

Sikora T., Odmieńcy / śmieci. Kultura Wspótczesna. Teorie. Interpretacje, Praktyka, 2007, no. 4(54), pp. 45-62.

Twardowski A., Disability studies jako przykład interdyscyplinarnego podejścia do niepetnosprawności, an unpublished manuscript, Poznań 2017.

Wittgenstein L., Dociekania filozoficzne, (trans.) B. Wolniewicz. Wydawnictwo Naukowe PWN, Warszawa 2004.

Wlazło M., Interdyscyplinarne studia nad niepełnosprawnością - sprzymierzeniec czy wróg pedagogiki specjalnej? Problemy Edukacji, Rehabilitacji i i Socjalizacji Osób Niepełnosprawnych 23/2, pp. 65-74, 2016.

Wolfe K., What is Posthumanism? University of Minnesota Press, Minneapolis 2010. file:// /C:/Users/user/Desktop/What\%20is\%20Posthumanizm.pdf. Access: 22.04.2019 r.

Wróblewski M., Choroba jako hybryda. ADHD w świetle Teorii Aktora-Sieci i Asocjologii, Studia Socjologiczne 2011, no. 4, pp. 121-154.

Zizek S., Przemoc. Sześć spojrzeń z ukosa, (trans.) A. Górny, Warszawskie Wydawnictwo Literackie Muza, Warszawa, 2010.

Zybertowicz A., Przemoc $i$ poznanie. Studium $z$ nie-klasycznej socjologii wiedzy. Wydawnictwo Naukowe Uniwersytetu Mikołaja Kopernika, Torun 2005.

Żółkowska T., Wyrównywanie szans społecznych osób z niepetnosprawnościa intelektualna, Inplus, Szczecin 2004. 